\title{
A DEMOCRACIA NO BRASIL
}

\section{Presidencialismo, coalizão partidária e processo decisório'}

\author{
FERNANDO LIMONGI
}

\begin{abstract}
RESUMO
Nada autoriza tratar o sistema político brasileiro como singular. Coalizões obedecem e são regidas pelo princípio partidário. O presidente, que teve seu poder institucional reforçado pela Constituição de 1988, detém monopólio sobre iniciativa legislativa, o que aproxima o sistema brasileiro das democracias parlamentaristas européias. Ainda que estruturada em torno de questões empíricas, a discussão tangencia questões teóricas, como a importância das escolhas institucionais e como estas afetam as relações entre a maioria e a minoria em governos democráticos.
\end{abstract}

\begin{abstract}
PALAVRAS-CHAVE: sistema político; democracia; teoria democrática; presidencialismo.
\end{abstract}

\section{SUMMARY}

There is no reason to treat the Brazilian political system as a singular one. Coalitions obey and are built according to party principles. The president, whose institutional power was enhanced by 1988's Constitution, monopolizes legislative initiative, which puts Brazilian system close to European parliamentary democracies. Even though its based upon empirical data, this essay formulates theoretical problems, such as the importance of institutional choices and how they affect relations between majority and minority in democratic governments.

\begin{abstract}
KEYWORDS: political system; democracy; democratic theory; presidentialism.
\end{abstract}

Para Adam Przeworski, meu professor

[1] Versão levemente modificada da aula proferida em 29/09/2006 durante as provas do concurso de Professor Titular no DCP/USP.
O tema desta aula, conforme o edital, é presidencialismo de coalizão e processo decisório no Brasil contemporâneo. Creio ser esta uma boa oportunidade para ampliar o enfoque e mostrar que é um equívoco traçar linhas demarcatórias rígidas entre, por exemplo, a pesquisa empírica e a teoria, entre métodos quantitativos e qualitativos e assim por diante. Cientistas políticos têm mostrado uma tendência a se dividir em tribos e pequenos grupos, cada um deles reivindicando para si o papel de herdeiro ou arauto da verdadeira disciplina. 
Não acredito que existam diferentes tradições ou idiomas em disputa. Quando trabalhadas de forma consistente, as indagações que estruturam a disciplina desrespeitam essas fronteiras. Por exemplo, questões que, à primeira vista, podem parecer meramente empíricas ou quantitativas, só podem ser respondidas de maneira adequada see quando as dimensões teóricas envolvidas são levadas em conta. Argumentos não podem ser contestados com base em suas alegadas origens geográficas. A lógica da análise científica não tem sotaque.

O tema central desta exposiçãoé o sistema político brasileiro, o seu modo de funcionamento e de operação, sistema este que, de uns tempos a esta parte, passou a ser nomeado pela expressão cunhada por Sérgio Abranches em 1988, isto é, como um presidencialismo de coalizão². O termo ganhou o grande público e, hoje, é de uso corrente, freqüentando inclusive os editoriais dos jornais de ampla circulação3.

A necessidade de adjetivar ou qualificar o presidencialismo brasileiro deixa subentendido que este teria algo de peculiar, de especial. Não praticaríamos um presidencialismo normal ou corriqueiro. Teríamos um regime com características próprias. Para bem ou para o mal, o presidencialismo brasileiro funcionaria desta forma particular: como um presidencialismo de coalizão.

Um dos objetivos centrais desta exposição é examinar se existem razões que autorizam essa aspiração à originalidade. Parafraseando O’Donnel, estaríamos frente a um novo animal político? Viveríamos sob um presidencialismo de coalizão, com direito a grifo e itálico?

Quando proposto por Sérgio Abranches, o uso do termo de fato comportava a reivindicação à especificidade:

O Brasil é o único país que, além de combinar a proporcionalidade, o multipartidarismo o o 'presidencialismo imperial', organiza o Executivo com base em grandes coalizões. A esse traço peculiar da institucionalidade concreta brasileira chamarei, à falta de melhor nome, 'presidencialismo de coalizão'.4

Nesse texto, a especificidade é diretamente associada às dificuldades da instauração de uma ordem democrática estável no Brasil. Nãoé demais lembrar o subtítulo do artigo: "o dilema institucional brasileiro". O texto é repleto de referências à possibilidade de crises e juízos acerca das dificuldades enfrentadas pelo país em suas experiências com um regime democrático. Cito apenas uma:

O raciocínio acima aponta para o nó górdio do presidencialismo de coalizão. É um sistema caracterizado pela instabilidade, de al to risco e cuja sustentação baseia-se, quase exclusivamente, no desempenho corrente do governo e nasua disposição de respeitarestritamente os pontos ideológicos ou
[2] Sérgio Henrique Abranches. "O presidencialismo de coalizão: o dilema institucional brasileiro". In: Dados 31(1), 1988, pp.5-33.

[3] Leia-se, por exemplo, o editorial de OEstado de S. Paulo, de 03 de junho de 2006, intitulado "Sucessão de vexames": "Mas o PMDB sabe que não precisará se aliar formalmente nem ao PT nem à coligação PSDBPFL, que também o corteja - nãoéde bom tom, naturalmente, falar em afinidades programáticas - para nos próximos quarto anos estar no poder federal, do qual jamais se afastou desde a redemocratização, salvo no acidental interregno collorido. É a lógica do presidencialismo de coalizão brasileiro".

[4] Abranches, op.cit., pp. 21-22. 
[5] Ibid, p. 27

[6] Ibid, p.22.

[7] Giovanni Sartori. "Concept Misformation in Comparative Politics". In:American Political Science Review 64(4),1970, pp.1033-53. programáticos considerados inegociáveis, os quais nem sempre são explícita e coerentemente fixados na fase de formação da coalizão. 5

Faz-se necessário precisar qual a contribuição do autor para o debate institucional do período pré-constituinte, a saber, propor uma alteração no foco da discussão, reconhecendo que de pouco adiantaria reformar a legislação partidária e eleitoral com vistas à redução do número de partidos. Presidentes sempre seriam forçados a formar coalizões para governar, mesmo, por paradoxal que pareça, se seu partido fosse majoritário. Isso porque coalizões não seriam formadas apenas de acordo com o critério partidário. Ou melhor, esse método usual de formação de coalizões seria insuficiente para dar a sustentação política necessária ao presidente. Federalismo, o poder dos governadores e a diversidade e heterogeneidade da sociedade brasileira, mais do que o número de partidos, tornavam coalizões imperiosas. Essa característica da política brasileira é afirmada na seguinte passagem:

A lógica da formação de coalizões tem, nitidamente, dois eixos: o partidário e o regional (estadual), hoje como ontem. É isso que explica a recorrência das grandes coalizões, pois o cálculo relativo à base de sustentação política do governo não éapenas partidário-parlamentar, mas também regional. ${ }^{6}$

O que distinguiria o presidencialismo de coalizão seria esse critério particular usado para a formação da base parlamentar de apoio ao presidente, isto é, o fato de ela não poder ser estritamente partidária. A necessidade de atender ao critério regional, vale insistir, se deve à heterogeneidade social do país, ao federalismo e ao poder dos governadores.

Sendo compostas dessa forma, conclui-se que, a despeito de necessárias, as coalizões seriam ineficientes, incapazes de apoiar agendas consistentes de governo. A coalizão, portanto, entra na definição do conceito não como solução, mas como expressão das dificuldades enfrentadas pelo presidente para governar.

No entanto, cabe perguntar se a formulação original é resgatada quando, hoje, se emprega o termo. Afinal, o que se tem efetivamente em mente quando nosso sistema é nomeado como um presidencialismo de coalizão?

Eu diria que a relação com a definição e caracterização original é vaga, quando não ambígua. Estamos diante, creio eu, do fenômeno apontado por Sartori muitos anos atrás: um esgarçamento conceitual que leva, irremediavelmente, à confusão. Ainda assim,é possível apontar para alguns pontos em que o texto de Abranches, cujos juízos atuais me parecem distantes dos oferecidos em 1988, tangenciam a visão corrente sobre o sistema político brasileiro. Este tende a servisto como original, em função da incapacidade de formar coalizões estritamente 
partidárias dada a fragilidade dos partidos, o que se explica em parte ou totalmente com referências à sobrevivência do poder tradicional (poder regional e local).

Minha exposição caminha na direção oposta. Do ponto de vista descritivo, o sistema político brasileiro, não há dúvidas, pode ser nomeado como um presidencialismo de coalizão. Afinal, a forma de governo adotada é o presidencialismo e governos recorrem à formação de coalizões para obter apoio para suas iniciativas. Logo, em si mesmas, essas características não implicam ou justificam a aspiração à originalidade. Mais do que isso, se recorrermos a evidências empíricas sistemáticas, como procurarei mostrar, não é possível manter quer a aspiração à originalidade, quer os juízos negativos. Ainda que trate apenas tangencialmente dos demais pontos, mostrarei também que não é possível sustentar que o partidos brasileiros não são capazes de estruturar coalizões partidárias ou que o poder tradicional regule e controle os resultados eleitorais.

Sendo mais positivo, quero mostrar que do ponto de vista da sua estrutura, da forma como efetivamente funciona, há pouco que permita distinguir o sistema político brasileiro de outras democracias ditas avançadas ou consolidadas. A forma como o processo decisório é organizado, mais especificamente, o poder de agenda conferido ao Executivo, garante que o governo brasileiro opere em bases similares às de grande parte das democracias existentes. Nesse aspecto particular, a Constituição de 1988 alterou radicalmente as bases institucionais sobre as quais se estruturam as relações entre o Poder Executivo e o Legislativo. Abranches, cabe notar, não faz qualquer referência ao processo decisório e escreve antes da elaboração da Constituição de 1988. Ou seja, ao utilizar o termos hoje, implicitamente, equiparamse as duas experiências democráticas brasileiras. No entanto, a matriz institucional de cada uma delas está longe de ser a mesma.

O plano da apresentação, feita a longa introdução, é o seguinte. $\mathrm{O}$ primeiro passo é estabelecer a aproximação entre o modo em que operam as democracias atuais e democracia brasileira. Trata-se, portanto, de introduzir elementos comparativos que permitam contextualizar nosso sistema político. A referência, claro, devem ser as democracias existentes e não as idealizadas. Por trivial e óbvio que pareça, esse não é o caminho usualmente trilhado pela maioria dos analistas.

Procurarei mostrar que o modo de operar do governo brasileiro éo mesmo da maioria das demais democracias contemporâneas. O Executivo controla a agenda legislativa, logrando aprovar a maioria de suas proposições porque ancorado por sólido e consistente apoio partidário. Por isso, esta seção pode ser nomeada, recorrendo a um linguajar burocrático-regimental, como tratando da estrutura e do funcionamento das democracias contemporâneas. 
Passo em seguida a analisar as possíveis objeções. Isto é, a discutir as dificuldades em aceitar que as informações dadas possam ter o mesmo significado aqui e alhures. Sendo alhures a Europa e países parlamentaristas, entende-se o argumento de que a realidade ganha significado diverso quando atravessa o Atlântico e pousa em terras inóspitas, tropicais. Assim, nomeio a segunda parte desta exposição como tratando das objeções.

Discutirei três grupos de objeções relacionadas à interpretação dos dados apresentados. As duas primeiras tratam de questões teóricas e analíticas. Começo pela própria possibilidade de estabelecer a comparação feita. É lícito comparar a estrutura dos governos parlamentaristas e presidencialistas? Dados relativos ao sucesso e à hegemonia legislativa do Executivo teriam, de fato, o mesmo significado nas duas formas de governo? Ou seja, a primeira objeção diz respeito à forma de governo, à distinção entre presidencialismo e parlamentarismo.

Já o segundo conjunto de objeções questiona a interpretação dos dados. Paralisia e incapacidade do Executivo em implementar sua agenda são compatíveis com altas taxas de aprovação das matérias legislativas. Bastaria, para tanto, que o Executivo reconhecesse sua fraqueza e submetesse à apreciação do Congresso apenas as matérias consensuais. Reúno essas objeções sob o subtítulo da agenda e da antecipação das reações.

A terceira objeção trata mais diretamente do debate nacional, mais precisamente, das arraigadas desconfianças quanto à qualidade de nosso corpo representativo. Pretender equiparar o Brasil, digamos, à Inglaterra seria desconsiderar as diferenças qualitativas entre o corpo representativo dos dois países. A natureza das maiorias seria radicalmente diversa. Sendo assim, a objeção remete diretamente à arena eleitoral e, em última análise, trata-se de discutir uma variação do velho diagnóstico segundo o qual o sistema político brasileiro poderia ser caracterizado pelo conflito entre um Executivo progressista e um Congresso conservador. Assim, o terceiro grupo de objeções pode ser intitulado das falhas do governo representativo no Brasil.

\section{DA ESTRUTURA E DO FUNCIONAMENTO DOS GOVERNOS DEMOCRÁTICOS}

Alguns poucos dados são suficientes para caracterizar os governos parlamentaristas contemporâneos. Dois indicadores bastante simples servem para apontar traços essenciais da forma como operam: a taxa de sucesso das iniciativas do Executivo, que nada mais é do que a proporção do que é aprovado sobre o total enviado por este poder, e a taxa de dominância sobre a produção legal, a simples divisão das leis cuja proposição se deve ao Executivo pelo total de leis aprovadas no período. Estudos comparativos e sobre países tendem a confirmar o 
que, em 1979, Loewenberg e Petterson ${ }^{8}$, em estudo comparativo pioneiro, chamaram da regra dos $90 \%$. Isto é: tanto a taxa de sucesso como a de dominância tendem a se concentrar em torno dos 90\%.

Os dados compilados pelo Inter Parliamentary Union', o levantamento comparativo mais confiável a esse respeito, não deixam margem a dúvidas. Alguns poucos exemplos bastam. O governo inglês, paradigma de governo parlamentarista, teve aprovada 93\% das propostas que submeteu ao parlamento entre 1971 e 1976. Entre 1978 e 1982, a taxa caiu um ponto percentual. Quanto à dominância, ela foi de $83 \%$ e $84 \%$ em cada um desses períodos. Os valores variam muito pouco. Um outro exemplo:a Dinamarca. No primeiro período coberto pelo levantamento, as taxas de sucesso e dominância foram respectivamente $89 \%$ e $99 \%$. Na pesquisa mais recente, os números caíram levemente, ficando em $88 \%$ e $97 \%$. A Finlândia, país que, como o Brasil, adota a representação proporcional com lista aberta, registra valores altos em ambos os quesitos nos dois períodos: $84 \%$ tanto de sucesso quanto de hegemonia entre 1971 e 1976 , subindo para $88 \%$ e $99 \%$ respectivamente no segundo período.

Os exemplos podem ser multiplicados. Contudo, registra-se, há países parlamentaristas incluídos na pesquisa que mostram comportamento atípico. Dois casos chamam a atenção, incluídos apenas na segunda edição: Portugal (13,7\% e 39,9\%) e Itália (51,3\% e 69,9\%). As exceções são importantes para chamar a atenção para dois pontos. Primeiro: a esfera de abrangência das normas legais pode afetar o comportamento do índice, como é o caso de Portugal em função da inclusão das "bagatelas", leis que alteram o status de vilas e freguesias no cômputo da produção legal. A Itália alerta para a possibilidade de que o predomínio do Executivo sobre a produção legal não seja um traço constitutivo do parlamentarismo. Primeiros-ministros tendem a controlar a agenda legislativa, mas não é necessário que assim seja.

A tendência geral contida nesses dados não é razão para soar sinais de alarme, istoé, não são interpretados como sinais da falência do Poder Legislativo ou de seu abastardamento diante do Executivo. Isso porque na origem da supremacia do Executivo estaria uma delegação expressa da maioria. As altas taxas de disciplina do partido ou da coalizão partidária que apóia o Executivo seriam a comprovação dessa delegação.

O complemento necessário para a compreensão das taxas de sucesso e dominância do Executivo em governos parlamentaristas, portanto,é a existência da disciplina partidária, dado que se toma como inconteste e indisputável para a maioria dos governos parlamentaristas. Tal suposição é de tal forma arraigada que é difícil encontrar trabalhos empíricos comparativos sobre o tema. Os poucos estudos dedicados a países específicos, por exemplo, tendem a contar votações em que um ou mais votos indisciplinados foram registrados ${ }^{10}$.
[8] Gerhard Lowenberg \& Samuel Patterson. Comparing legislatures. Boston: Little Brown, 1979 .

[9] Valentine Hermamn \& Françoise Mendel. Parliaments of the world: a reference compendium. London: Inter-Parliamentary Union/De Gruyter, 1976; e, dos mesmos autores, Parliaments of the world: a reference compendium. Berlin and New York: Inter-Parliamentary Union, 1986.

[10] Análises do parlamento inglês podem ser encontradas em Edward W. Crowe. "Cross-Voting in the British House of Commons: 1945-1974". In: The Journal of Politics, v. 42, 1980; John E. Schwarz. "Exploring a New Role in Policy Making: The British House of

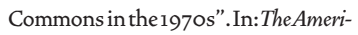
can Political Science Review, n. 74, 1980; Philip Cowley e Philip Norton. "Rebels and Rebellions: Conservative MPs in the 1992 Parliament". In: British Journal of Politics and International Relations, 1(1), 1999 . 
[11] Os dados para produção legislativa e disciplina partidária foram atualizados até março de 2006 .
Essas informações, de certa forma, revelam a estrutura dos governos parlamentaristas, as bases sobre as quais seu funcionamento ordinário repousa: supremacia do Executivo amparada por apoio partidário consistente. Pois muito bem, e o Brasil? As referências constantes a problemas de governabilidade, à fragilidade do quadro partidário e o apelo permanente a uma reforma política apontariam ou nos fariam supor que o quadro a ser revelado pelo exame de dados similares seria radicalmente diverso. Estaríamos diante de problemas de governabilidade se o governo se mostrasse incapaz de governar. Partidos seriam frágeis se incapazes de dar sustentação política às propostas do governo. No entanto, o exame dos dados revela quadro radicalmente diverso. O Brasil não é tão diferente dos países parlamentaristas. Senão, vejamos.

Comecemos pelas taxas de sucesso e dominância. Elas são elevadas, comparáveis às observadas nos países que analisamos momentos atrás. O sucesso do Executivo para o período pós-promulgação da Constituição de 1988 é de $70,7 \%{ }^{11}$. Cabe notar que a definição de sucesso adotada é exigente, pois pede que a matéria seja aprovada ao longo do mandato do presidente que submeteu a medida. As variações por presidentes são pequenas e independem da sua base de apoio. É certo que Fernando Collor, o único presidente do período a formar coalizões minoritárias, teve o pior desempenho nesse quesito entre todos os presidentes, aprovando $65 \%$ dos projetos que submeteu. Mas a variação é menor que a estabilidade. A taxa de sucesso para Itamar foi um ponto superior à de Collor e os demais presidentes ficaram um pouco acima dos $70 \%$.

A taxa de dominância para o mesmo período também é expressiva: $85,6 \%$. Uma vez mais, não há variações significativas entre os mandatos. Collor e Sarney têm os valores mais baixos, em torno dos $77 \%$. Itamar e Lula estão acima dos 90\%, enquanto Fernando Henrique teve taxa similar em seus dois mandatos: $85 \%$.

É interessante comparar esses dados não apenas com países parlamentaristas. Compará-los ao período democrático anterior tambémé revelador. O contraste não poderia ser mais completo. O sucesso do Executivo no período para o qual há dados disponíveis (1949-1964) foi um magro $29,5 \%$. Vargas, o mais bem sucedido presidente do período logrou aprovar apenas $45 \%$ do que enviou. Quanto às taxas de dominância, as diferenças soam igualmente palpáveis. O Executivo foi responsável pela apresentação de $39 \%$ das leis aprovadas naquele período. Uma vez mais, o presidente com a taxa mais alta na primeira experiência democrática está bem inferior ao presidente que teve piores resultados no período atual: a diferença que os separa é de $30 \%$.

Ou seja, as relações Executivo-Legislativo mudaram da água para o vinho. E mudaram por força das diferenças entre os dois textos cons- 
titucionais. Visto pelo ângulo da produção legislativa, o mais bem sucedido presidente do período anterior não é sequer uma pálida imagem dos presidentes atuais. Estamos diante de características que decorrem da estrutura institucional adotada e não das qualidades pessoais deste ou daquele líder.

Para resumir: o que o Executivo submete ao Legislativo é, em geral, aprovado.E, por definição, as matérias só podem ser aprovadas se contam com o apoio da maioria. Para evitar mal entendidos, cabe notar que a afirmação se estende às Medidas Provisórias. Estas necessitam ser aprovadas pelo Congresso para que se tornem leis.

O passo seguinte posto para a análise é investigar o comportamento da maioria, isto é, saber como o Executivo obtém apoio para suas propostas. Uma vez mais, a análise empírica revela um quadro inesperado. O governo brasileiro é bem sucedido na arena legislativa porque conta com o apoio sólido de uma coalizão partidária.

Disciplina é a norma. Deputados filiados aos partidos que fazem parte da coalizão de apoio ao presidente seguem a recomendação de voto do líder do governo. A disciplina média da base do governo proporção de deputados filiados a partidos que receberam pastas ministeriais que votaram em acordo com a indicação expressa do líder do governo - é de $87,4 \%$ nas 842 votações ocorridas no período ${ }^{12}$. A variação entre presidentes é pequena: a menor média foi registrada sob Sarney, com 78,4\%, e a maior, 90,7\%, no segundo governo de Fernando Henrique. O governo Lula, para dissipar falsas imagens, contou com apoio médio de $89,1 \%$ dos deputados da base do governo em 164 votações.

$\mathrm{Na}$ realidade, a bancada do governo perde consistência quando um dos partidos da base não segue a liderança do governo, quando a taxa de apoio cai para 70,1\% ${ }^{13}$. No entanto, essas dissensões no interior da base são relativamente raras, tiveram lugar em 18\% das 786 votações consideradas.

Comparados à disciplina quase absoluta registrada na maioria dos países parlamentaristas, esses números podem até ser considerados baixos. Contudo, o que realmente importa não é a magnitude da disciplina, mas a previsibilidade, isto é, se líderes têm como prever os resultados, se podem garantir vitórias contando apenas com suas bancadas. E isso ocorre no Brasil. O plenário é extremamente previsível.

O fato é que o presidente raramente é derrotado. O governo saiuse vitorioso em nada mais nada menos que 769 das 842 votações consideradas: 91,3\% das vezes. Não há grande variação se distinguimos tipos de votação, dado o quorum exigido ou se a votação se referia ou não a matéria substantiva. No caso das matérias constitucionais, em que se exige $3 / 5$ dos votos favoráveis para aprovação da emenda, a porcentagem de vitórias está exatamente na média, foram 242 vitórias em
[12] Só são consideradas válidas as votações de matérias ordinárias em que o quorum regimental foi alcançado e as não unânimes, istoé,em que há desacordo entre as indicações dos líderes ou a minoria teve pelo menos $10 \%$ dos votos válidos. Para calcular a disciplina da base do governo, é preciso saber a posição do governo.

[13] Existe dissensão interna à base sempre que um dos líderes dos partidos da base indicou voto em desacordo com o líder do governo. 
[14] José Antonio Cheibub, Adam Przeworski e Sebastian Saiegh. "Governos de Coalizão nas Democracias Presidencialistas". In: Dados 45(2), 2002, pp. 187-218.
265 votações. Em seu segundo governo, Fernando Henrique obteve apoio do plenário em 31 das 32 votações e Lula, em 31 das 32.

Com base nessas informações, parece difícil sustentar que a base de apoio do governo careça de solidez. Vale observar que na maioria das derrotas, a indisciplina da base não foi o problema, mas sua divisão interna, isto é, pelo menos um partido não seguiu a orientação do líder do governo.

Por último, antes de prosseguir, cabe notar que presidentes podem correr riscos que, por vezes, primeiros-ministros não podem, uma vez que derrotas não implicam perda do cargo. Logo, é de esperar que o governo, sob presidencialismo, sofra maior número de derrotas sem que isso signifique paralisia ou conflito insuperável com o Legislativo ${ }^{14}$.

Analisados dessa forma, os dados permitem concluir que estamos diante de negociações partidárias, levadas a cabo pelas lideranças dos partidos que formam a base do governo. Dissensões na base são raras, como indicam os poucos casos em que a coalizão se divide. Dito de maneira inversa: nada indica que o sucesso do Executivo seja obtido caso a caso, matéria a matéria, com maiorias formadas a partir de negociações individuais.

O governo controla a produção legislativa e esse controle é resultado da interação entre poder de agenda e apoio da maioria. Maioria reunida por uma coalizão partidária pura e simples. Nada muito diverso do que se passa nos governos parlamentaristas. Ou seja, não há bases para tratar o sistema político brasileiro como singular. Muito menos, para dizer queestaríamos diante de uma democracia com sérios problemas, ameaçada por alguma síndrome ou patologia causada quer pela separação de poderes, quer pela fragilidade de seus partidos.

Ainda assim, impera a desconfiança e a visão negativa. Há enormes dificuldades em aceitar que vivamos sob uma democracia normal. $\mathrm{O}$ nosso sistema político simplesmente não poderia ser equiparado às demais democracias. Passemos, então, às objeções. Porque objeções há. E não são poucas.

\section{DAS OBJEÇÕES}

Obviamente, é impossível, dados os limites desta exposição, tratar de todas as objeções que podem ser levantadas às proposições feitas na seção anterior. Creio ter selecionado as mais representativas. Tratarei de três objeções, as relativas à forma de governo, à seleção estratégica das propostas e à natureza da maioria. Quanto à primeira delas, a que se refere à forma de governo, seu cerne toma a seguinte forma: o sucesso e a dominância do Executivo seriam traços normais sob o parlamentarismo; sob o presidencialismo, seriam evidências de anomalias, de uma clara deturpação do princípio da separação dos 
poderes, uma vez que a tarefa de legislar deveria caber ao Legislativo. Sob presidencialismo, caberia ao Executivo executar as leis cuja elaboração estaria a cargo do Poder Legislativo. Assim, se o Executivo é o principal legislador, teríamos uma usurpação do Poder Legislativo pelo Poder Executivo.

Para dar início à discussão, é importante ressaltar quão inadequado é identificar o funcionamento virtuoso do presidencialismo seja à sua concepção original, seja ao modelo norte-americano contemporâneo.Ambos os erros, creio, são cometidos pela literatura comparada atual15.

Nos debates acerca do presidencialismo, é usual a referência aos Federalistas. Na maioria das vezes, não passa de uma reverência: uma consulta ao oráculo, para relembrar a ironia com que Madison trata as referências a Montesquieu pelos anti-federalistas. Consulta, no entanto, que perde de vista, de acordo com Bernard Manin, o essencial da contribuição original dos Federalistas: a de criar mecanismos endógenos para o controle e a limitação do exercício do poder pela maioria, dificultando a sua ação, tornando-a mais lenta ${ }^{16}$. Quero ressaltar esse ponto porque o entendimento das relações entre maioria e minoria em desenhos institucionais específicos é uma referência constante nesta exposição.

É interessante notar a assimetria no tratamento dedicado aos governos parlamentaristas e presidencialistas. O parlamentarismo moderno, cuja expressão clássica se encontra no governo inglês, não foi o resultado de um desenho institucional previamente concebido. Antes o contrário. A fusão de poderes Executivo e Legislativo apontada por Bagehot, o que denominou como seu segredo eficiente, ia contra a separação de poderes louvada e recomendada pela teoria vigente. ${ }^{17}$

Como mostra Gary $\operatorname{Cox}^{18}$, a concentração de poderes nas mãos do gabinete foi o resultado não intencional de uma série de transformações iniciadas com a ampliação do eleitorado em 1832. Como todos queriam aprovar propostas para agradar seu eleitorado, cresceu a pressão sobre o tempo escasso. Posteriormente, a reação à estratégia obstrucionista da bancada irlandesa reforçou o controle do primeiro-ministro sobre os trabalhos. Do ponto de vista do processo decisório, teve lugar uma verdadeira expropriação dos direitos legislativos individuais dos parlamentares. Minorias tiveram seu poder imensamente reduzido, quando não anulado. A maioria, de sua parte, passou a governar por meio da delegação ao gabinete. Processo análogo teve lugar em muitos regimes presidenciais. No entanto, o retorno constante ao "oráculo" acaba por condenar essa evolução, vendo-a como ilegítima ou como um atentado contra os venerados princípios da separação dos poderes. $O$ mais paradoxal dessa insistência é que não se trata de uma discussão
[15] Para dois exemplos acabados desse tipo de erro, consultar Terry Moe \& Michael Caldwell. "The Institutional Foundations of Democratic Government: a Comparison of Presidential and Parliamentary Systems". In:Journal Institutional and Theoretical Economics, 150(1), 1994, pp. 171-195; e Bruce Ackerman. "The New Separation of Powers". In: Harvard Law Review, 113(3), 2000, pp. 633-725.

[16] Conforme afirma Manin, a separação de poderes "aimed to place restraints on what the Federalists expected to be the predominant power, the power of the people.(...) The primary purpose of these two prominent checks and balances was thus to slow down the will of the people and to delay its action. These checks were not supposed to operate as bulwarks that stopped definitively the popular will, but only as obstacles which could be overcome, but after a while". Bernard Manin: "Checks, Balances and Boundaries: the Separation of Powers in the Constitutional Debate of 1787 ". In: Biancamaria Fontana (org.). The invention of modern Republic. Cambridge: Cambridge University Press, 1994, pp. 6o-61.

[17] A passagem relevante é a seguinte: "The brief description of the characteristic merit of the English Constitution is that its dignified parts are very complicated and somewhat imposing, very old and rather venerable; while its efficient part, at least when in great and critical action, is decidedly simple and rather modern. (...) The efficient secret of the English Constitution may be described as the close union, the nearly complete fusion of the executive and the legislative powers. According to the traditional theory, as it exists in all books, the goodness of our constitution consists in the entire separation of the executive and legislative authorities, but in truth its merit consists in 
their singular approximation. The connecting link is the cabinet. By that new word we mean a committee of the legislative body selected to be the executive body. (...) The legislature chosen, in name, to make laws, in fact finds its principal business in making and in keeping an executive". Walter Bagehot. The English Constitution. Cambridge: Cambridge University Press: 2001, pp. 8-9.

[18] Gary Cox. The efficient secret: the cabinet and the development of political parties in Victorian England. Cambridge: Cambridge University Press, 1987.

[19] Terry Moe. "An Assessment of the Positive Theory of 'Congressional Dominance'". In: Legislative Studies Quarterly, XII(4), 1987, pp.475-520.

[20] Essa observação irônica é feita por Terry Moe e Scott Wilson. "Presidents and the Politics of Structure". In: Law and Contemporary Problems 57, 1994, pp 1-44.

[21] Consultar a respeito: William Howell. Power without persuasion: the politics of direct presidential action. Princeton: Princeton University Press, 2003. Para uma excelente comparação entre as Medidas Provisórias e as Executive Orders, consultar Marco Aurélio Sampaio.A medida provisória como ato de governo. Tese de doutorado. Faculdade de Direito da USP, 2004.

[22] Fernando Limongi. "Formas de Governo, Leis Partidárias e Poder de Agenda". In: Boletim Informativo e Bibliográfico, 55, 2003, pp.7-39.

[23] “The definition of (...) 'pure' presidentialism is the following: (1) the popular election of the chief executive; (2) the terms of the chief executive and assembly are fixed, and are not contingent on mutual confidence; and (3) the elected executive names and directs the composition of the government; (4) the president has some constitutionally granted lawmaking authority". Mathew Shugart e John Carey. Presidents and assemblies. Cambridge: Cambridge University Press, 1992, p. 19.

[24] O Artigo 161, parágrafo primeiro, da Constituição de 1988 estabelece que "são de iniciativa exclusiva do Presidente da República as leis que I fixem ou modifiquem os efetivos das Forças Armadas; II Disponham sobre que dependa da exegese e interpretação de textos escritos por autores consagrados. Basta ler os próprios textos constitucionais. Estes mudaram, afastando-se da matriz norte-americana.

A literatura comparada, sob forte influência dos estudos legislativos norte-americanos, minimiza o poder do presidente, insistindo, como sublinha Terry $\mathrm{Moe}^{19}$, em colocar o congresso no centro daquele sistema político. É inegável que do ponto de vista de seus poderes legislativos, o presidente norte-americano é fraco. Seu poder se limita ao veto total. Mas isso não o reduz à insignificância, a um mero ponto no espaço com poder similar ou inferior a um senador ${ }^{20}$. E notem que não é preciso considerar o verdadeiro poder de decreto com que contam os presidentes norte-americanos, as recentemente "descobertas" Excutive Orders, para criticar essa visão ${ }^{21}$.

As dificuldades para compreender o presidencialismo contemporâneo decorrem da tendência a equiparar separação a conflito entre os poderes. Na origem desse equívoco, como argumentei em outra oportunidade ${ }^{22}$, está a premissa de que políticos se importariam apenas com obter mandatos. Políticos, para usar o jargão e seguindo a proposta original de Downs, seriam office seeking. E como presidentes e legisladores respondem a eleitorados diversos, segue que têm interesses distintos, isto é, que procurarão enviesar as políticas públicas para eleitorados diversos. Portanto, inevitavelmente, entrarão em conflito.

Cabe observar que a conhecida e sempre citada definição de presidencialismo proposta por Shugart e Carey se baseia, sobretudo, na separação eleitoral dos mandatos ${ }^{23}$. O que tornaria presidencialismo e parlamentarismo diversos, o que impediria a cooperação dos poderes, seria a diferença quanto à origem e término dos mandatos. Da independência dos mandatos seria possível derivar a impossibilidade da cooperação entre os poderes. Vale notar de passagem que neste argumento, dada a premissa que o que realmente importa é obter e assegurar mandatos, legisladores são tratados como tendo interesse comum e único. O conflito intra-legislativo, os partidos, saem de cena.

O fato é que o presidente brasileiro é poderoso do ponto de vista legislativo não porque usurpe o poder legislativo, mas porque a Constituição de 1988 assim o estabeleceu. O presidente tem a prerrogativa exclusiva de iniciar legislação nas principais áreas de política: tributação, orçamento e fixação dos quadros do funcionalismo, para citar as áreas fundamentais ${ }^{24}$. Logo, o presidente não é um legislador qualquer.

Cabe notar: o presidente brasileiro não é o único a assumir essa posição.A maioria das constituiçõos presidencialistas estabelece esses mesmos princípios. Constituições presidencialistas adotadas mais recentemente não seguem o padrão norte-americano. Conferir ao presidente a prerrogativa exclusiva de iniciar as matérias legislativas mais relevantes tende a ser a norma. Sobretudo, limita-se a esfera de ação 
possível dos legisladores à definição do orçamento público. Essa açãoé circunscrita de forma clara e expressa. Por exemplo, no Brasil, a Constituição de 1988 disciplina a apresentação de emendas à proposta orçamentária, restringindo-as, praticamente, ao remanejamento de dotações destinadas a investimentos ${ }^{25}$. Várias outras constituições presidencialistas fazem o mesmo. Ironicamente, a caracterização do funcionamento e dos problemas enfrentados pelo presidencialismo oferecida por Juan Linz ${ }^{26}$ parece saída das páginas de Bagehot.

Em resumo, a Constituição brasileira, de par com outras tantas constituições presidencialistas, impede que as carreiras parlamentares sejam construídas recorrendo ao distributivismo. Os Estados Unidos dos anos cinqüenta e sessenta é que são a exceção. Deputados em governos presidencialistas tiveram, da mesma forma que no parlamentarismo, circunscritos seus direitos parlamentares de apresentar propostas ${ }^{27}$.

Sendo assim, o referencial analítico usado para compreender as relações entre o Executivo e o Legislativo sob parlamentarismo podem ser usados no estudo do funcionamento do presidencialismo. O processo decisório favorece o Executivo, que, contando com esses recursos, é capaz de estruturar e preservar sua base de apoio legislativa. Em ambos os casos, o Executivo governa amparado pela delegação da maioria.A distância entre governos presidencialistas e parlamentaristas é menor do que normalmente se supõe.

O exame dessas questões nos leva assim à segunda objeção, ao entendimento do significado das taxas de sucesso e hegemonia legislativa do presidente. De acordo com essa objeção, os indicadores de sucesso e hegemonia legislativa do presidente não seriam suficientes para provar a capacidade do presidente em aprovar sua agenda legislativa. Se o presidente fosse capaz de antecipar as reações, ou melhor, as objeções do Congresso, só proporia legislação que teria certeza de ser aprovada. Dessa possibilidade à conclusão de que isto de fato ocorre com a parte substantiva e que realmente importa da agenda presidencial é apenas um passo.

A objeção não é nova e ocupa posição central no interior da disciplina. Impossível não referi-la ao debate acerca das manifestações do poder, suas diferentes faces, para usar as expressões que se cristalizaram nos anos sessenta. Mais importante, a objeção nos força a ser rigorosos do ponto de vista analítico e, como mostrarei, se considerada desta forma, seu efeito é menor do que pode parecer à primeira vista.

Para que a objeção fique mais clara, recorro a uma citação, a uma de suas formulações mais completas, apresentada por Alfred Stepan ao questionar as conclusões de trabalhos que apresentam dados sobre o sucesso e a dominância legislativa do presidente brasileiro. A passagem relevante é a seguinte: a) criação de cargos, funções ou empregos públicos na administração direta ou autárquica ou aumento de sua remuneração; organização administrativa e judiciária, matéria tributária e orçamentária, serviços públicos e pessoal da administração dos Territórios".

[25] O artigo 166 da Constituição estabelece que as emendas ao orçamento só serão aceitas desde que "indiquem os recursos necessários, admitidos apenas os provenientes de anulação de despesa, excluídas as que incidam sobre: a) dotações para pessoal e seus encargos; b) serviço da dívida; c) transferências tributárias constitucionais para Estados, Municípios e Distrito Federal".

[26] Juan Linz. "Presidential or parliamentary democracy: does it make a difference?" In: Juan Linz \& Arturo Valenzuela (eds.). The failure of presidential democracy: the case of Latin America. Baltimore: Johns Hopkins University Press, 1994, pp.3-87.

[27] Por isso mesmo, o presidente chileno, entre 1990 e 1996, foi o responsável pela introdução de $86 \%$ das leis aprovadas (Peter M. Siavellis. The president and the congress in post-authoritarian Chile. Pennsylvania: Penn State University Press, 2000). Mesmo um presidente considerado fraco, como o venezuelano, foi responsável pela proposição de $84 \%$ das leis sancionadas entre 1959 e 1995 (Brian F. Crisp. Democratic institutional design: the powers and incentives of Venezuelan politicians and interest group. Stanford: Stanford University Press, 2000). 
[28] Alfred Stepan. "Para uma Análise Comparativa do Federalismo e da Democracia: Federações que Restringem ou Ampliam o Poder do Demos". In: Dados, 42(2), 1999, p. 231. Não é minha intenção discutir o texto de Stepan, mas sim a objeção levantada. Objeção similar se encontra em Barry Ames. Os entraves da democracia no Brasil. Rio de Janeiro: Editora FGV, pp. 243 ess.

[29] Peter Bachrach e Morton S. Baratz. "Two Faces of Power". In: The American Political Science Review, 56(4), 1962, pp 947-952. Ver também, dos mesmos autores, "Decisions and Non-decisions: an Analytical Framework". In: The American Political Science Review, 57(3), 1963, pp. 632-642.

[30] Keneth Shepsle. "The Changing Textbook of Congress". In: John Chubb \& Paul Peterson (eds.).Can the Government Govern? Washington: Brookings Institution, 1989 .
Nessas condições entra em jogo o que Karl Friedrich chamou de lei da resposta antecipada (...): dado que todos os jogadores conhecem o potencial de obstrução de uma pequena minoria, muitas medidas que poderiam contar como apoio de uma maioria do Congresso e da opinião pública são retiradas da agenda. ${ }^{28}$

Deixemos de lado uma saída fácil: a ressalva, em se tratando de uma lei, se aplicaria igualmente aos países parlamentaristas citados anteriormente. $\mathrm{O}$ tipo de questionamento invocado é mais amplo e geral. Trata-se de um problema a ser enfrentado sempre que relações de poder são discutidas. No interior da disciplina, uma de suas mais famosas e conhecidas encarnações se deu no conhecido debate entre os pluralistas e a teoria das elites. Como comprovar que o poder está disperso ou concentrado em poucas mãos?

No desenrolar desse debate, como é sempre recordado em qualquer revisão do tema, Brachrach e Baratz ${ }^{29}$, em 1962, chegaram justamente à lei da antecipação das reações, apontando para a existência de uma segunda face do poder. $O$ poder que se exerce sem se manifestar, isto é, quando um ator impede que temas cujas decisões possam vir a contrariar seus interesses sejam incluídos na agenda decisória. Teríamos, então, não-decisões. No que se refere a esta apresentação, teríamos questões não submetidas ao Congresso, uma agenda presidencial não proposta pela antecipação da obstrução do Congresso.

O problema é conhecido. Enunciá-lo não chega a ser propriamente uma objeção conseqüente. Seria preciso ir adiante para transformar o problema analítico em um questionamento com conseqüências empíricas e substantivas. Mas, mesmo no campo analítico, estamos hoje em melhores condições para enfrentar o problema posto pela possível antecipação das reações. Stepan aponta a direção. O uso do termo jogadores não é, por certo, gratuito.

O trecho citado é precedido por uma série de referências à literatura sobre o Congresso norte-americano, mais especificamente, à que adota a perspectiva da escola da escolha racional. Algumas questões envolvidas pela objeção levantada podem ser mais bem compreendidas quando referidas a essa literatura. Sendo mais preciso, cabe recuperar o debate substantivo e metodológico que tem lugar na literatura norteamericana. Quanto ao primeiro aspecto, o que está em jogo é o poder institucional das comissões, a capacidade das minorias encasteladas nas comissões terem suas propostas aprovadas pelo plenário. A visão estabelecida sobre o congresso norte-americano, The Textbook Congress $^{30}$, para parafrasear o título do conhecido artigo de Shepsle, frisa a descentralização do processo decisório e a importância que as comissões assumem nesse contexto. Nessa estrutura institucional, minorias com preferências em desacordo com a maioria acabariam por governar. 
Essa é uma visão estabelecida na literatura e que, cabe notar, antecede a aplicação de modelos da escolha social aos estudos legislativos.

O afamado modelo proposto por Shepsle não prova que comissões governem e que a descentralização do processo decisório leve ao governo por minorias, ainda que essa seja uma interpretação comum do seu trabalho31. A questão que Shepsle procura responder é outra. Seu problema é de ordem teórica e analítica. Ele recorre a uma versão estilizada do Congresso norte-americano para provar a existência de equilíbrio em decisões tomadas de acordo com a regra da maioria. Shepsle está procurando uma resposta para o problema da instabilidade e imprevisibilidade das maiorias. Decisões por maioria não seriam estáveis, não teriam equilíbrio. Para qualquer decisão tomada por uma maioria, seria possível formar uma coalizão majoritária alternativa que a derrotaria.

A impossibilidade de encontrar uma decisão social única, no entanto, ocorreria num suposto estado de natureza, num processo decisório não regulado por instituições, em que a vontade da maioria seria revelada pela mera agregação das preferências ${ }^{22}$. O modelo de Shepsle impõe estrutura a esse processo decisório, uma estrutura que espelha o sistema de comissões adotado pelo Congresso norte-americano. No entanto, em última análise, a solução proposta por Shepsle depende do parcelamento do processo decisório, da transformação de uma decisão multidimensional em uma série de decisões unidimensionais tomadas de forma independente pelas comissões.

Demonstrar a existência do equilíbrio não é o mesmo que mostrar que será alcançado. Equilíbrio neste texto significa que não há uma maioria que vote em favor de uma decisão alternativa. A definição de equilíbrio usada - core - não se pergunta como esta decisão seria obtida. Examina-se todo o espaço decisório em busca de um ponto com esta propriedade: não ser derrotada por qualquer maioria hipoteticamente formada. Nesta tradição, como e por que a maioria convergiria para este ponto não é uma questão investigada. No entanto, para que este ponto viesse a ser a decisão social, como mostra Krehbiel, seria necessário que o plenário acatasse as propostas das comissões que contrariam seus interesses. ${ }^{3}$ No cerne do argumento, está o problema da antecipação das reações e a seqüência em que atores são chamados a participar do processo decisório.

Tal objeção levou a um intenso debate sobre as bases institucionais do poder das comissões legislativas que acabou por desmentir a interpretação substantiva atribuída ao modelo proposto por Shepsle. ${ }^{34}$ Somente a deferência à expertise da comissão seria capaz de explicar por que o plenário acataria as propostas feitas pelas comissões. Do ponto de vista institucional e assumindo-se atores racionais, a comissão não tem como impor a sua vontade ao plenário.
[31] Keneth Shepsle. "Institutional Arrangements and Equilibrium in Multidimensional Voting Models". In: Mathew McCubbins \& Terry Sullivan (eds.). Congress: structure and policy. New York: Cambridge University Press, 1987.

[32] Suposto porque preferências precisam ser agregadas de acordo com regras. Ainda assim, os teóricos da escolha social afirmam que a instabilidade das maiorias se revelaria sob qualquer regra para agregar preferências conhecidas.

[33] Keith Krehbiel. "Sophisticated Committees and Structure-Induced Equilibrium in Congress." In: Mathew McCubbins \& Terry Sullivan (eds.). Congress: structure and policy. New York: Cambridge University Press, 1987.

[34] Kenneth Shepsle \& Barry Weingast. "The Institutional Foundations of Committee Power". In:American Political Science Review, 81, 1987, pp. 85-103. Keith Krehbiel. "Why are Congressional Committees Powerful?". In: American Political Science Review, 81, 1987, pp. 929-935. Kenneth Shepsle \& Barry Weingast. "Reflections on Committee Power." In:American Political Science Review, 81, 1987, pp. 935-45. 
[35] Por isso mesmo, no interior deste debate, a existência ou não da possibilidade de o plenário emendar as propostas feitas pelas comissões (closed ou open rules) e a capacidade do plenário retirar uma matéria das comissões por meio da discharge petition ser ou não efetiva assumem grande relevância. Deixo de lado essas questões assim como as inúmeras condições relacionadas ao debate sobre se as comissões são agentes de interesses especiais, dos partidos ou da maioria. Para uma revisão dessa literatura, consultar meu artigo: "O Novo Institucionalismo e os Estudos Legislativos: a Literatura Norte-Americana Recente". In: Boletim Informativo Bibliográfico, 37, 1994, pp.3-38.

[36] Não cooperativa porque a cooperação não pode ser assumida, mas sim, caso ocorra, tem que ser resultado das estratégias ótimas.

[37] Para uma revisão, consultar Daniel Diermeier \& Keith Krehbiel. "Institutionalism as a Methodology". In: Journal of Theoretical Politics, 15, 2003, pp. 123-144. David AustenSmith \& Jeffrey Banks. "Social Choice Theory, Game Theory, and Positive Political Theory". In:Annual Review of Political Science, 1998, pp. 259-287.
Ao longo desse debate, Krehbiel introduziu uma distinção aparentemente banal, mas crucial para as questões substantivas envolvidas ao observar a diferença entre o poder de veto (o poder negativo, na sua linguagem) eo poder de aprovar propostas contrárias aos demais atores (o poder positivo). Nas duas situações, apesar do significado diverso que possuem, dizemos que um ator (no caso da discussão, a minoria representada pela comissão) impõe a sua vontade ao outro (a maioria, representada pelo plenário). Mas há uma diferença crucial entre as duas situações.

Krehbiel sustenta que comissões teriam, no máximo, um poder negativo, o poder de bloquear. Como são rotas obrigatórias para a tramitação das matérias, a comissão fecharia as portas às propostas que sabe seriam decididas contrariamente a seu interesse pelo plenário. A comissão prefere deixar as coisas como estão, o status quo, às mudanças que seriam introduzidas pelo plenário. Nas demais situações, o poder das comissões depende das restrições impostas ao direito do plenário emendar as propostas que faz.

Obviamente, não é meu interesse reconstituir ou mesmo precisar o poder das comissões legislativas norte-americanas. Estou recorrendo a esse debate para frisar a importância das relações entre o desenho institucional eo poder conferido às maiorias e minorias em sistemas políticos democráticos. O modelo original do governo por comissões é um modelo em que a minoria governa. No modelo revisado, levada em conta as críticas feitas por Krehbiel, minorias deteriam um poder conservador, seriam capazes de deter a maioria. Ainda assim, cabe notar, terão esse poder sob um desenho institucional específico. No caso, desde que não seja possível a maioria contornaro poder de veto das preferências minoritárias encasteladas na comissão35.

Comissões, certamente, não são a única forma pela qual minorias podem deter a vontade da maioria. É, no entanto, uma das mais estudadas e eficientes armas das minorias em governos democráticos.A minoria pode recorrer a outras estratégias, como estender indefinidamenteo debate, provocar votações a todo o momento, negar quorum, etc.

A discussão substantiva sobre o poder das comissões norte-americanas foi acompanhada, do ponto de vista metodológico, pelo progressivo abandono dos modelos baseados na escola da escolha social (public choice) e da teoria dos jogos cooperativa. Os modelos atuais seguem as premissas da teoria dos jogos não-cooperativa ${ }^{36}$. Na literatura especializada, é usual distinguir duas gerações de modelos ${ }^{37}$. Os modelos da primeira geração carecem de postulados comportamentais minimamente consistentes. Basicamente, recorrem a regras ou métodos pré-estabelecidos para agregar preferências, sem explicar ou fornecer razões para justificar por que os atores agem da forma como agem. Quem quer que estude o célebre modelo de McKelveyélevado a 
se perguntar por que os atores não percebem que estão se afastando do conjunto de decisões Pareto-Ótimas. Tudo se passa como se o único ator racional, a agir de forma estratégica, fosse o ator que controla a agenda. Por isso mesmo, em função dessa inconsistência, esses modelos foram abandonados e substituídos pelos modelos baseados na teoria dos jogos não cooperativa.

O fato é que se recorrermos à teoria dos jogos não cooperativa, a lei da antecipação das reações é sempre aplicada. Jogadores raciocinam tendo em mente as conseqüências das suas ações. Logo, adotam os cursos de ação que levam ao melhor resultado que podem obter. Agem de maneira estratégica, antecipando, a cada passo, a sua contribuição para o resultado final. Krehbiel mostrou, por exemplo, que o modelo do governo por comissões repousa sobre premissas inconsistentes acerca do comportamento dos atores.

Voltando ao Brasil, cabe investigar quais os efeitos do desenho institucional sobre o poder da maioria e da minoria. Se retornarmos à formulação da lei da antecipação das reações apresentada, esta estipula que minorias deteriam o poder de vetar, isto é, de bloquear as propostas do Executivo.

Se olharmos para a estrutura institucional brasileira veremos, no que tange às propostas de lei ordinária, que essa possibilidade simplesmente não existe. A maioria tem como evitar que a minoria ou minorias venham a bloquear as propostas que considere relevantes.

Comissões, para permanecer no campo que vínhamos discutindo, não podem "engavetar" propostas. A maioria conta com vários expedientes para forçar a apreciação das propostas pelo plenário — o mais importante deles, sem dúvida, a tramitação em regime de urgência. A aprovação de um requerimento de urgência permite que a minoria seja contornada, uma vez que acarreta a apreciação praticamente imediata da matéria pelo plenário e, além disso, restringe o direito à apresentação de emendas. Na verdade, há três tipos de urgência. Em primeiro lugar, temos a chamada urgência constitucional, isto é, prevista pelo texto constitucional e que pode ser solicitada unilateralmente pelo Presidente da República ${ }^{3}$, que tem assim como forçar o plenário a deliberar sobre as matérias que submete ao Poder Legislativo. As duas outras formas de urgência são aprovadas pelo próprio Poder Legislativo e, enquanto tal, reguladas pelos respectivos regimentos. O Artigo 151 do Regimento Interno da Câmara dos Deputados estabelece que o regime de tramitação pode ser alterado de ordinário para especial no caso de matérias "reconhecidas, por deliberação do Plenário, de caráter urgente". Em termos práticos, a aprovação da solicitação de urgência significa que a matéria é retirada da Comissão e incluída na ordem do dia para apreciação pelo plenário. Há ainda a possibilidade de se aprovar, de acordo com o Artigo 155, a tramitação em regime de urgên-
[38] O Artigo 164 da Constituição assim estabelece: "Parágrafo $1^{\circ}$.O presidente poderá solicitar urgência para apreciação de projetos de sua iniciativa. Parágrafo $2^{\circ}$. Se no caso do Parágrafo $1^{\circ}$ a Câmara dos Deputados e o Senado Federal não se manifestarem sobre a proposição, cada qual, sucessivamente, em até quarenta e cinco dias, sobrestar-se-ão todas as demais deliberações legislativas da referida Casa, com exceção das que tenham prazo constitucional determinado, até que se ultime a votação". 
[39] Artigo 155: "Poderá ser incluída automaticamente na Ordem do Dia para discussão e votação imediata, ainda que iniciada a sessão em que for apresentada, proposição que verse sobre matéria de relevante e inadiável interesse nacional, a requerimento da maioria absoluta da composição da Câmara, ou líderes que representem esse número, sem a restrição do parágrafo segundo ao artigo precedente".

[40] Artigo 62 da Constituição: "Em caso de relevância e urgência, o Presidente da República poderá adotar medidas Provisórias, com força de lei, devendo submetê-las de imediato ao Congresso Nacional". cia urgentíssima, um pleonasmo verdadeiramente maravilhoso que vem a significar a votação imediata da matéria39.

Propositalmente, deixei por último a arma mais poderosa com que conta o presidente, o poder de decreto, a medida provisória ${ }^{4 \circ}$, para mostrar que se trata de um entre outros tantos recursos à disposição do presidente. O mais poderoso sem dúvida alguma, pois altera unilateralmente o status quo. No entanto, não pode ser usado contra a maioria.A passagem de uma medida provisória a lei depende de aprovação legislativa. Para o ponto em discussão, importa notar que a minoria não tem como impedir que o presidente edite uma medida provisória.

Em uma palavra: a minoria não tem como impedir que matérias sobre as quais a maioria ou o Executivo definam como relevantes venham a voto. Então, ao contrário do que muitos afirmam, as instituições brasileiras não são desenhadas para vetar, para paralisar. Os expedientes usuais para barrar decisões, recursos a que minorias recorrem para protelar decisões contrárias a seus interesses, simplesmente não estão presentes no sistema político brasileiro. $O$ desenho institucional favorece a maioria.

Analisada à luz da realidade institucional brasileira, a lei da antecipação das reações não faz com que o presidente tenha razões para temer o veto das minorias. No entanto, consideremos uma versão modificada da lei da resposta antecipada: "dado que todos os jogadores conhecem o potencial de obstrução da maioria, muitas medidas que fazem parte da agenda do Executivo sequer são enviadas à apreciação do Congresso".

Posta nestes termos, a questão muda inteiramente de figura. A maioria legislativa tem esse poder de veto em qualquer sistema que chamemos de democrático. A agenda do Executivo não pode ser imposta contra a vontade da maioria.A não ser que se queira argumentar que a vontade do Executivo seja, de alguma forma, ou com base em um critério qualquer, superior a do Legislativo.

Creio que parte considerável dos juízos negativos acerca da performance da democracia brasileira baseia-se nesse pressuposto, isto é, no julgamento, implícito ou explícito, de que em caso de conflito, a vontade do Executivo deveria prevalecer sobre a do Congresso. Trata-se, como procurarei demonstrar, de um eco da conhecida fórmula "presidente progressista versus Congresso conservador". Onde, obviamente, entende-se que o progressista seja superior ao conservador e que, portanto, deveria prevalecer.

Antes de passar a esse ponto, podemos aprofundar o entendimento das relações entre o Executivo e a maioria. Podemos especificar melhor os conflitos potenciais entre Executivo e Legislativo, distinguindo algumas situações paradigmáticas. Conflito pode significar interesses opostos, um jogo de soma zero. Mas há situações em que 
ambas as partes preferem um conjunto de alternativas ao status quo, mas disputam ou divergem quanto à alternativa específica a ser implementada. Há, nesse caso, espaço para negociações e barganhas em torno da divisão dos benefícios da cooperação.

Se trabalharmos com modelos bastante simples, construídos a partir das premissas usuais de espaço unidimensional, informação perfeita e preferências com pico único, tudo que temos a consideraréa posição relativa de três pontos em uma linha: o ponto ideal do presidente, da maioria e o status quo. Para resolver o jogo, tudo que temos a fazer é medir distâncias. Atores racionais sempre preferem os pontos mais próximos ao seu ponto ideal. No interior desses modelos, e não há qualquer pretensão a novidade na análise proposta, o controle da agenda traz enormes vantagens, vantagens diretamente derivadas da lei da antecipação das reações.

Como vimos, a Constituição de 1988 assegura ao Executivo a prerrogativa exclusiva de iniciar legislação nas áreas de política mais importantes. Ou seja, o presidente controla a agenda. A tradução desse dispositivo legal em termos do modelo em análise significa simplesmente assumir que o presidente se move em primeiro lugar. Pode, portanto, fazer suas propostas antecipando as reações dos demais.

Há, basicamente, três situações a considerar. Uma primeira possibilidade (ver figura 1) coloca o presidente entre o status quo e a maioria. Nesse caso, presidente e maioria querem deslocar a política na mesma direção. A posição do presidente, no entanto, é mais moderada que a do Congresso. Se o presidente puder vetar as emendas indesejáveis, isto é, que trazem a proposta para o ponto ideal do Congresso, a sua vontade prevalece. Como o veto pode ser derrubado, o presidente pode ser forçado a moderar suas pretensões. No entanto, mesmo considerando o veto, não precisa ceder inteiramente à maioria e poderá aprovar uma medida que se situe em seu ponto ideal e o da maioria ${ }^{41}$.

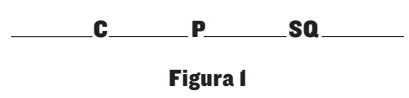

Uma segunda possibilidade inverte estas posições, istoé, teríamos da direita para a esquerda, presidente, congresso e status quo ${ }^{42}$. A situação é análoga e parte do raciocínio usado na situação anterior pode ser transplantado para este caso. $O$ presidente aqui terá que calibrar a sua proposta, tornando-a aceitável para o Congresso. O presidente pode se mover no segmento de seu ponto ideal ao do Congresso tanto quanto for a distância entre este e o status quo. Essa distância pode ou não ser suficiente para que a proposta seja o seu ponto ideal. Se o presidente for um extremista, será forçado a moderar a sua proposta. Mas sempre será capaz de pular o ponto da maioria, trazendo a política mais em sua direção.
[41] Isso porque, por construção, a posição da maioria qualificada capaz de derrubar o veto deve se situar entre o ponto ideal do presidente e o do congresso. Em termos práticos, a ameaça de derrubada do veto pode ser desconsiderada. Para uma análise dos vetos, ver Mauricio Assumpção Moya. Executivo versus Legislativo: os vetos presidenciais no Brasil de 1988 a 2000. Tese de doutorado, departamento de Ciência Política, USP, 2006.

[42] O leitor pode adaptar facilmente a figura 1 a esta nova situação. 
[43] Por exemplo, os modelos propostos por John Huber (Rationalizing Parliament: Legislative institutions and party politics in France. Cambridge: Cambridge University Press, 1996) e por William Howell (Power Without Persuasion. The Politics of Direct Presidential Action. Princeton: Princeton University Press, 2003) podem ser adaptados para mostrar, respectivamente, como os poderes de agenda do presidente brasileiro podem ser usados para "proteger" a unidade da coalizão e superar, via edição de medidas provisórias, bloqueios mútuos.

[44] Para um modelo com informação incompleta, consultar Charles Cameron. Veto Bargaining, Cambridge: Cambridge University Press 2000 .
Nesses dois casos, estamos diante de situações em que há lugar para barganha. Ambas as partes ganham com a cooperação, mas há inúmeras possibilidades de divisão desses ganhos. O poder de agenda com que conta o presidente faz com que ele maximize seus ganhos potenciais. Ele pode escolher a melhor proposta para si entre as que se encontram no interior do conjunto das propostas que a maioria aceitará. Esse ganho é produto direto do controle sobre a agenda combinado à antecipação das reações.

A terceira e última situação é aquela em que as diferenças entre o governo e a maioria os coloca em lados opostos do status quo. Nessa situação, não há ganhos que possam ser auferidos por uma possível barganha ou negociação. A maioria e o Executivo querem mover o status quo em direções contrárias. Nesta situação, o status quo prevalece. No entanto, cabe notar, pela antecipação das reações, é o presidente que frustra as pretensões da maioria. Somente nesse caso, a agenda do presidente se torna uma não-agenda.

Creio ter lidado com o segundo conjunto de objeções. A existência de uma possível não-agenda não é suficiente para questionar as conclusões sugeridas. As razões para aproximar a forma de operação do governo brasileiro com os governos parlamentaristas são reforçadas. $\mathrm{O}$ poder de agenda está na base do poder do Executivo em ambas as formas de governo. Sucesso e dominância legislativa assim como a disciplina partidária são funções diretas do controle que o Executivo exerce sobre o conteúdo, a forma e o momento em que matérias são votadas.

Pode-se argumentar que os modelos considerados são extremamente simples, baseados em premissas irrealistas que os tornariam sem grande importância do ponto de vista do jogo político real. No entanto, os modelos seguem as premissas em que a objeção foi levantada. A lei da antecipação das reações supõe informação completa. A objeção foi testada em suas próprias premissas.

O quadro não é alterado se considerarmos modelos mais complexos, quer se mantenha a premissa da informação completa ${ }^{43}$, quer se considere jogos dinâmicos e com informação incompleta44. Para os fins desta apresentação, não cabe enveredar por estas possibilidades. Analisei a objeção em seus próprios termos com base em modelos conhecidos e amplamente utilizados na literatura. Chama a atenção que a maioria dos críticos se contente em relembrar a lei da antecipação das reações, tomando o seu mero enunciado como uma objeção de peso. O fato é que se consideradas de forma sistemática, a objeção apenas reforça a posição de destaque do Executivo.

Muitos não se convencerão. Análises formais como as feitas acima assumiriam uma estrutura que não seria encontrada no Brasil. Faria sentido supor a existência de uma maioria que apóia o Executivo? Chegamos assim à terceira e derradeira objeção. O que está em jogo é 
a natureza da maioria legislativa, a sua legitimidade para negociar, obter concessões e barrar as propostas do Executivo. Como disse antes, parte dos juízos negativos acerca da performance da democracia brasileira é alimentada pela desqualificação e depreciação do Poder Legislativo, questionando-se de maneira sutil e oblíqua a legitimidade dos seus interesses. Só assim é possível ver as concessões do Executivo à sua base de apoio como indicador de crise de governabilidade. No entanto, até prova em contrário, a versão modificada da lei da antecipação das reações - isto é, a necessidade da agenda do Executivo contar com apoio da maioria - é uma regra básica de todo e qualquer governo democrático.

Retorno, para caracterizar melhor essa objeção e relacioná-la ao tema desta exposição, a Abranches e à sua caracterização do presidencialismo de coalizão. Cabe recordar que em sua formulação original, a coalizão que pode apoiar o presidenteé marcada pela heterogeneidade de sua composição. Em artigo mais recente, escrito em 2001 , ao longo do segundo mandato de Fernando Henrique Cardoso, Abranches resgata o conceito para entender as dificuldades que o governo enfrentava naquele momento ${ }^{45}$. $\mathrm{O}$ autor afirma que a raiz do problema seria de ordem sociológica e não institucional ${ }^{4}$. Relações fisiológicas e clientelísticas pautariam as relações entre os eleitores e seus representantes e, como conseqüência, as relações entre o Executivo e o Legislativo. Vale citar uma longa passagem do texto:

Não creio que o fisiologismo e o clientelismo sejam intrínsecos ao regime de governança. Eles são componentes do padrão de relacionamento entre partidos e eleitores, portanto um dado sociológico. Se os partidos majoritários logram conquistar essa maioria por meio desse tipo de mecanismo de manipulação do eleitor despossuído e não há alternativas competitivas em muitos redutos, a relação entre a maioria legislativa e o Executivo terá, de fato, um elevado grau de propensão ao fisiologismo e ao clientelismo. Mas seria assim, se o governo não fosse de coalizão. 47

O problema, portanto, está na maioria, ou melhor, no modo pelo qual mandatos são obtidos. O partido do presidente poderia ser majoritário e as dificuldades permaneceriam as mesmas uma vez que "a maioria continuaria majoritariamente fisiológica e clientelista" 48 . $\mathrm{O}$ problema é de ordem sociológica e não institucional porque repousa, em última análise, na "sobrevivência dessas formas oligárquicas de dominação política em vários subsistemas políticos no país".49

Os termos empregados — redutos não competitivos, eleitor pobre e manipulado, sobrevivência de formas oligárquicas de dominação, clientelismo e oligarquia - têm conotações claras, sobretudo em uma análise que chama a atenção para a importância do federalismoe, mais
[45] Sérgio Henrique Abranches. "A Democracia Brasileira Vai Bem Mas Requer Cuidados". In: João Paulo dos Reis Velloso (org.). Como vão a democracia e o desenvolvimento no Brasil? Rio de Janeiro: José Olympio, 2001, pp. 251-277.

[46] "Estou convencido de que o fundamento dessa complexidade e de tal complicação da governança no Brasil é sociológico e não redutível a problemas de regulação ou ordenamento institucional." Abranches, op. cit., pp. 269-270.

[47] Ibid, p. 268.

[48] Ibid, p. 269.

[49] Ibid, p. 263. 
[50] Victor Nunes Leal. Coronelismo, enxada e voto: o município e o regime representativo no Brasil. São Paulo: Alfa-Ômega, 1993, p. 253.

[51] "Finalmente, a abolição do regime servil e, depois, com a República, a extensão do direito do sufrágio deram importância fundamental ao voto do trabalhador rural.Cresceu, portanto, a influência política dos donos de terra, devido à dependência dessa parcela do eleitorado, conseqüência direta de nossa estrutura agrária, que mantém os trabalhadores da roça em lamentável situação de incultura e abandono. Somos, nesse particular, legítimos herdeiros do sistema colonial da grande exploração agrícola, cultivada pelo braço escravo e produtora de matérias-primas e gêneros alimentícios destinados à exportação. A Libertação jurídica do trabalho não chegou a mudar profundamente esse arcabouço, dominado ainda hoje, grosso modo, pela grande propriedade e caracterizado, quantoà composição de classe, pela sujeição de uma gigantesca massa de assalariados, parceiros, posseiros e ínfimos proprietários à pequena minoria de fazendeiros, poderosa em relação a seus dependentes, embora em posição cada vez mais precária o conjunto da economia nacional". Victor Nunes Leal, 1993, p. 253.

[52] Orlando de Carvalho. "Ensaios de Sociologia Eleitoral". Revista de Brasileira de Estudos Políticos, 1958, p. 99. especificamente, para o poder dos governadores. No entanto, o que pretendo frisar é que, em última análise, o argumento levanta suspeições sobre a legitimidade dos mandatos da maioria.

Estou, é claro, levando o argumento do autor ao extremo, retirando partes do texto de seu contexto, isolando os mecanismos invocados. Procuro dessa forma tão somente estabelecer a linha de continuidade do argumento apresentado no interior das interpretações acerca do sistema representativo brasileiro. A referência óbvia aqui é ao trabalho de Victor Nunes Leal, à sua conhecida interpretação do coronelismo como um sistema que pressupõe "uma relação de compromisso entre o poder privado decadente e o poder público fortalecido" cuja baseé a

superposição do regime representativo, em base ampla, a essa inadequada estrutura econômica e social, havendo incorporado à cidadania ativa um volumoso contingente de eleitores incapacitados para o consciente desempenho de sua missão política, vinculou os detentores do poder político, em larga medida, aos condutores daquele rebanho eleitoral. 50

Para o desenvolvimento do argumento, interessa frisar a referência ao descompasso entre o poder político e o poder social. Um grupo social em declínio é sobre-representado em função da capacidade de transformar o controle social que exerce sobre trabalhadores e agregados em votos, em recursos políticos. Em Nunes Leal, cuja referência maior, mas não exclusiva, é a República Velha, trata-se, já, de uma sobrevivência, de um poder político defasado em relação ao desenvolvimento social. A previsão é de que este poder mingue, que perca sua importância ${ }^{51}$.

Com a democratização, os estudos pioneiros de sociologia eleitoral nos anos 50 e 60 , reafirmam os pilares do argumento de Nunes Leal.Por exemplo, Orlando de Carvalho, examinado a primeira década de eleições sob o regime democrático conclui:

Cremos que se pode caracterizar nitidamente a tendência do eleitorado, querem Minas, quer no Brasil, para afastar-se dos grandes partidos de centro, considerando como tais PSD, UDN e PR. (...) São partidos que, no âmbito nacional, repousam em elementos conservadores e têm por base de sua força o eleitorado rural. 52

Aalteração de registroé menor que a continuidade na passagem do coronel para os partidos conservadores (partidos de centro na tipologia empregada por Orlando de Carvalho. O que importa ressaltaréque este diagnóstico, implicitamente, associa a força eleitoral dos partidos conservadores (de direita) à sobrevivência do controle social do proprietário de terra sobre sua clientela.A despeito das inovações institu- 
cionais que acompanham a democratização em 1945, notadamente a introdução da Justiça Eleitoral, a descrição de Nunes Leal se aplica aos dois períodos: "Os votos dos partidos conservadores se devem à dependência do elemento rural ao fazendeiro, impedindo o contato direto dos partidos com essa parcela notoriamente majoritária do nosso eleitorado" 53 . Os proprietários de terra "conduzem magotes de eleitores como quem toca tropa de burros" 54 garantido assim a supremacia eleitoral da direita e seu controle sobre a maioria das cadeiras.

O poder político da direita passa a ser explicado como uma sobrevivência, como resultado da persistência de formas arcaicas de dominação55. Assim, enquanto partidos conservadores obtiverem votos, estes podem ser explicados pela existência de um volumoso contingente de eleitores incapacitados para o consciente desempenho de sua missão política, à persistência do atraso e ao poder das oligarquias. Partindo deste suposto, os resultados eleitorais, sobretudo os votos obtidos pelos partidos de direita, podem ser explicados recorrendo à alegada ausência de autonomia do eleitorado, sem que, com tempo, seja necessário fazer referência ao proprietário de terra. Preserva-se, no entanto, a percepção de um desajuste entre o poder político e o social, seguida da reafirmação da expectativa de seu breve desaparecimento,

Trata-se de uma visão difusa, mas que informa parte substancial do debate político brasileiro. Nessa perspectiva, com algum exagero, podemos dizer que a direita se encastela no Congresso e entrava as mudanças de que o país realmente deseja. A despeito de seu desalinho com as tendências socioeconômicas do presente, seu descompasso com as transformações seculares, como se dizia tempos atrás, as forças do atraso têm como resistir. De alguma forma, têm mais votos do que deveriam ter.

Voltando ao debate atual. De fato, ainda existem redutos em que não há competição eleitoral? Ainda sobrevive, modificado e adaptado ao mundo moderno, o voto de cabresto? Afinal, se a maioria obtiver seus votos em redutos eleitorais não competitivos manipulando a vontade da maioria do eleitorado pobre e carente, então estamos diante de uma maioria que obteve seus mandatos de forma questionável, sem a necessária legitimidade democrática, revelando assim o pecado original que vicia a representação no Brasil e sua expressão no Congresso.

Essas proposições podem ser testadas. Obviamente, nenhum teste empírico vai ser cabal. Pode, no entanto, abalar convicções e certezas.

Aocasião não é a mais propícia, dado o formato desta apresentação, para um exame detalhado de dados que levem à reconsideração dessas objeções. Pretendo, apenas, inverter o ônus da prova. Istoé, quero mostrar que o recurso às fórmulas conhecidas é insuficiente para sustentar as suspeitas acerca da qualidade do processo eleitoral brasileiro e dos resultados que ele produz, a qualidade dos representantes incluída.
[53] Leal, op. cit., p. 42. Vale observar que esta afirmação é precedida de análise da estrutura fundiária baseada em dados do Anuário Estatístico de 1946.

[54] Ibid., p. 43.

[55] A formulação mais conhecida do declínio dos partidos conservadores em função da erosão de suas bases se encontra em Glaucio Ary Dillon Soares. Sociedade e Política no Brasil. São Paulo: Difusão Européia do Livro, 1973. 
[56] Uso coligações e não partidos porque são aquelas, não estas, as unidades que de fato disputam cadeiras. Obviamente, coligações podem ser formadas por um único partido. Por definição, o número efetivo de partidos eleitorais será maior que o de coligações.

[57] O valor será igual a um se uma lista granjear $100 \%$ dos votos no município. Será igual a dois se dois partidos obtiverem a mesma porcentagem devotos. Será três, se três partidos receberem caprichosamente $33 \%$ dos votos eassim pordiante. No entanto, a relação não é unívoca. Por exemplo, é possível obter umvalor igual a três partidos efetivos sem que tenhamos três partidos iguais. Emgeral, à medida que o número se afasta de um, menor a proporção de votos obtida pela lista que obteve mais votos.
Dados muito simples e palmares permitem contestar a hipótese da persistência de redutos eleitorais não competitivos. A competitividade de um reduto - equiparado a um município na análise que segue - pode ser aferida pelo número efetivo de listas eleitorais, as coligações ${ }^{56}$. Quanto mais próximo de um for este número, menor a competição real.À medida que este número tende a dois, mais próximos estamos da certeza de que existe competição57.

O número efetivo médio de coligações eleitorais por município é de 2,94 considerando-se os 5665 municípios brasileiros. Há, por certo, municípios não competitivos, mas são uma minoria. Somente 320 municípios registram um valor inferior a 1,5 coligações eleitorais efetivas. Votaram nesses municípios apenas 1,7\% dos eleitores que compareceram às urnas no pleito de 2002. Barra do Corda, no Maranhão, é o único município com mais de 30 mil votantes nessas condições. A vasta maioria desses municípios tem um número reduzido de eleitores. Em 296 deles, o número de votos válidos esteve abaixo de dez mil. Portanto, são poucos os redutos não competitivos e como eles se concentram nos municípios menores, representam uma porcentagem reduzida do eleitorado.

Não segue que todos os municípios pequenos sejam não competitivos. São 3964 municípios com comparecimento inferior a dez mil eleitores, onde votaram $18,6 \%$ dos votantes. O número efetivo de coligações eleitorais entre esses municípios foi de 2,8 , isto é, muito próximo à média nacional. Mesmo quando a média de número efetivo de coligações é estratificada por Estados, restringindo-se aos municípios com comparecimento inferior a dez mil eleitores, só três Estados registram médias inferiores a 2,0: Tocantins $(1,6)$, Amazonas $(1,7)$ e Pernambuco $(1,97)$. Considerando sucessivamente grupos de cidades menores, é preciso restringir a análise a municípios com comparecimento inferior a 2500, para encontrar um Estado, o Amazonas, com média abaixo de 1,5 coligações eleitorais efetivas.

Competição, está claro, não é facilmente mensurável. Não é necessário, dados os limites desta exposição e os propósitos desta discussão específica, buscar medidas mais refinadas deste conceito. Recorri a estatísticas descritivas básicas para ressaltar o ponto:é difícil não se dar conta de quão competitiva se tornou nossa democracia. Dadas essas informações, o ônus da prova troca de mãos: cabe aos críticos do funcionamento de nossa democracia especificar suas falhas. Obviamente, não constitui qualquer avanço nesse sentido mostrar os desvios em relação a democracias idealizadas. O desafio está em mostrar as diferenças em relação a democracias existentes.

Para completar o quadro, para chegar à maioria no interior do Poder Legislativo, reconstituí a votação dos deputados eleitos na eleição de 2002 , procurando identificar sua dependência para com os 
votos obtidos em municípios não-competitivos. Arbitrariamente, foram tidos como não-competitivos os redutos em que o número efetivo de coligações foi inferior a 1,5. O candidato pode ou não pertencer a essa lista. Basta que tenha tido votos naquele município para considerá-lo como representante daquele eleitorado. Ou seja, a dependência dos parlamentares para com redutos não-competitivos é inflada. $O$ que se quer captar é o peso dos redutos não-competitivos para a composição do Congresso.

Dos 513 deputados eleitos em 2002,274 tiveram ao menos um voto em municípios não competitivos. Praticamente não existem parlamentares dependentes desse tipo de reduto. Somente três parlamentares receberam mais de $40 \%$ do total de sua votação em redutos não-competitivos (Rogério Silva, PMDB, MT), Maurício Rabelo (PSD, TO) e Darci Coelho(PFL, TO).Apenas 17 deputados receberam percentagens superior a $20 \%$ de seus votos em distritos desta natureza.Aoutra cauda da distribuição concentra um número maior de casos. São 239 deputados sem um voto sequer em municípios não competitivos, enquanto para 115 parlamentares os votos desses municípios representou menos de $1 \%$ do seu total. O número de deputados com dependência inferior a $5 \%$ chega a 311, isto é, suficiente para aprovar uma emenda constitucional. Em resumo, para a vasta maioria dos parlamentares, a contribuição dos redutos não competitivos é desprezível.

Se deputados respondem a seus eleitores, se suas relações com o Executivo são pautadas pela forma como conseguem votos, parece difícil sustentar que estejamos diante de políticos que controlam "magotes" de eleitores. Na verdade, esses dados apontam apenas na direção do óbvio: o eleitorado brasileiro é hoje predominantemente urbano e, sob essas condições, não há como invocar a sujeição de um eleitor isolado e dependente social e economicamente para explicar os resultados. Se controle houver, recursos e explicações devem se adaptar às condições vigentes.

Creio ter mostrado os limites da última objeção. Não me parece que se possa sustentar que a competição eleitoral no Brasil apresente vícios que maculem a representação. Não há razões para questionar a legitimidade dos mandatos obtidos pelos legisladores. Pode-se não gostar dos resultados, mas essa é uma questão de ordem inteiramente diversa. O mandato do Executivo não é mais legítimo que o da maioria parlamentar com que ele é forçado a negociar.

\section{DAS CONCLUSÕES}

Nada autoriza tratar o sistema político brasileiro como singular. Coalizões obedecem e são regidas pelo princípio partidário. Não há paralisia ou síndrome a contornar. A estrutura institucional adotada 
Recebido para publicação em 10 de novembro de 2006.

\section{NOVOS ESTUDOS}

CEBRAP

76 , novembro 2006

pp. 17-41 pelo texto constitucional de 1988 é diversa da que consta do texto de 1946. O presidente teve seu poder institucional reforçado. Para todos os efeitos, a Constituição confere ao presidente o monopólio sobre iniciativa legislativa. A alteração do status quo legal, nas áreas fundamentais, depende da iniciativa do Executivo. Entende-se assim que possa organizar seu apoio com base em coalizões montadas com critérios estritamente partidários. Para influenciar a política pública é preciso estar alinhado com o presidente. Assim, restam aos parlamentares, basicamente, duas alternativas: fazer parte da coalizão presidencial na legislatura em curso, ou cerrar fileiras com a oposição esperando chegar à Presidência no próximo termo.

É equivocado insistir em caracterizar nosso sistema por suas alegadas falhas, pelas sua carências. Inverter a perspectiva, no entanto, só torna a tarefa mais difícil, pois implica aceitar a necessidade de explicar o real, não de condená-lo ou censurá-lo.

Para fazê-lo, para apreender como de fato opera o sistema político brasileiro, é preciso, como procurei mostrar, reconhecer que não existem diferentes tradições ou idiomas em disputa. As indagações que estruturam a disciplina desrespeitam as falsas fronteiras erigidas para separar a teoria da empiria. E assim é, quer se estude o Brasil, quer se estude outra democracia qualquer. Ainda que guiada e estruturada em torno de questões empíricas, a discussão tangenciou temas centrais à disciplina, como a importância das escolhas institucionais e como estas afetam as relações entre a maioria e a minoria em governos democráticos. Remetem, portanto, ao cerne da teoria democrática.

FERNANDO LIMONGI é professor titular no departamento de ciência política da USPe e pesquisador do Cebrap. 